\title{
Measurement of Nasal and Exhaled Nitric Oxide in Nasal Disease
}

\author{
Myung Chul Shin, Keon Jung Lee, Seung Hwan Lee, \\ Seok Hyun Cho, Kyung Rae Kim and Jin Hyeok Jeong \\ Department of Otolaryngology-Head and Neck Surgery, College of Medicine, Hanyang University, Seoul, Korea
}

\author{
비 질환에서 비강 및 호기 산화질소의 측정 \\ 신명철 · 이건중 · 이승환 · 조석현 · 김경래 · 정진혁 \\ 한양대학교 의과대학 이비인후-두경부외과학교실
}

Received December 8, 2010

Revised January 31, 2011

Accepted February 8, 2011

Address for correspondence

Jin Hyeok Jeong, MD

Department of Otolaryngology-

Head and Neck Surgery, College of

Medicine, Hanyang University,

249-1 Gyomun-dong, Guri 471-701,

Korea

Tel $+82-31-560-2368$

Fax +82-31-566-4884

E-mail ent@hanyang.ac.kr
Background and Objectives Nitric oxide (NO) is present in high concentrations in the upper respiratory tract. The physiological role of this mediator is to contribute to the local host's defense, modulate ciliary motility and serve as an aerocrine mediator in helping to maintain adequate ventilation-perfusion matching in the lung.

Subjects and Method The purpose of the study was to assess the relationship of nasal NO (nNO) and exhaled NO (eNO) in nasal airway disease patients. NO concentration was measured using a chemiluminescence analyzer. $\mathrm{nNO}$ was analyzed by aspiration at a sampling flow rate of $700 \mathrm{~mL} / \mathrm{min}$ with velum closure. eNO was analyzed during expiration against a constant resistance of $10 \mathrm{~cm} \mathrm{H}_{2} \mathrm{O}$.

Results NO concentration of the normal control group $(n=32)$ was compared with that of the allergic rhinitis group $(n=31)$ and the rhinosinusitis with that of the nasal polyp group $(n=$ 30 ). The mean nNO level in the control group was $241 \pm 89 \mathrm{ppb}$ and eNO was $20.5 \pm 6.4 \mathrm{ppb}$. The mean $\mathrm{nNO}$ level was significantly increased in the allergic rhinitis group ( $332 \pm 125 \mathrm{ppb})$ but decreased in the chronic sinusitis group $(89 \pm 55 \mathrm{ppb})$. The mean eNO level was significantly increased both in the allergic rhinitis group (26.9 $\pm 10.1 \mathrm{ppb})$ and chronic sinusitis group (29.8 $\pm 12.8 \mathrm{ppb})$.

Conclusion $\mathrm{nNO}$ concentration was increased in patients with allergic rhinitis and decreased in patients with chronic sinusitis; however, eNO was increased in both patients. This shows that patients with upper respiratory inflammation may also have lower respiratory inflammation, supporting the concept of 'one airway, one disease'. This study shows that measurement of NO is useful for the study or evaluation of nasal diseases.

Korean J Otorhinolaryngol-Head Neck Surg 2011;54:197-202

Key Words Nitric oxide $\cdot$ Allergic rhinitis $\cdot$ Rhinosinusitis.

\section{서 론}

산화질소(nitric oxide, NO)는 높은 반응성의 무기 유리 기로 이전에는 단순히 공해 물질로 알려졌으나, 혈관확장에 작용하는 효소임이 알려지면서 생물학적으로 많은 관심을 받는 물질로 생체 신호 전달 및 방어 작용에 관여한다고 알 려져 있다. $\mathrm{NO}$ 는 반감기가 $6 \sim 10$ 초로 짧은 기체 상태이므
로 직접적인 연구가 어려워, 생체 내에서 L-arginine으로부 터 $\mathrm{NO}$ 를 생산해내는 $\mathrm{NO}$ synthase에 대한 연구나 $\mathrm{NO}$ 의 대사산물인 질산염, 아질산염에 대한 연구 등 간접적인 방 법이 주로 이용되어 왔다. 해외에서는 간접적인 연구보다는 직접적인 기체 상태의 $\mathrm{NO}$ 측정에 많은 연구가 이루어지고 있으나 국내에서는 천식에서 구강을 통해 측정하는 하기도 기원의 호기 산화질소(exhaled $\mathrm{NO}, \mathrm{eNO})$ 에 대한 연구 ${ }^{1)}$ 만 
있을 뿐, 비강을 통해 측정하는 상기도 기원의 비강 산화질 소(nasal NO, nNO)를 직접 측정한 연구는 아직까지 전혀 이루어지지 않았다. 이에 국내에서는 한번도 이루어지지 않 은 $\mathrm{nNO}$ 측정법을 소개하고, 정상인에서 $\mathrm{nNO}, \mathrm{eNO}$ 를 측 정하여 한국인에서 그 정상치를 추정해 보고, 이를 상기도 염증성 질환에서 어떤 차이가 있는지 알아보고자 한다.

\section{대상 및 방법}

\section{대 상}

대조군으로는 비중격만곡증 환자 32 명, 환자군으로는 알 레르기 비염 환자 31 명, 비용을 동반한 비부비동염 환자 30 명 등 총 93명의 환자를 대상으로 하였다(Table 1).

비중격만곡증으로 비중격교정술을 시행한 32 명을 정상 대조군으로 하였으며, multiple allergosorbent test(MA$\mathrm{ST}$ ) 또는 알레르기 피부반응검사로 알레르기 비염은 제외하 였고, 부비동 단순 촬영 또는 부비동 전산화단층촬영 $(\mathrm{CT})$

Table 1. The demographic and characteristics of the patient group and control group

\begin{tabular}{lccc}
\hline & Control group & \multicolumn{2}{c}{ Patient group } \\
\cline { 3 - 4 }$(n=32)$ & $\operatorname{AR~}(n=31)$ & Sinusitis $(n=30)$ \\
\hline Age (years) & $27.3(13-55)$ & $33.4(10-61)$ & $24.4(14-54)$ \\
Sex $(M: F)$ & $16: 16$ & $22: 9$ & $16: 14$ \\
\hline
\end{tabular}

AR: allergic rhinitis
으로 비부비동염을 제외하였으며, 폐기능 검사를 시행하여 천 식을 제외하였다. 정상 대조군의 평균 나이는 27.3세(13 55)였 고, 남자 16 명, 여자 16 명이었다.

알레르기 비염 환자는 병력 및 알레르기 검사를 통해 알레 르기 비염으로 진단되었고, 영상의학적 검사에서 비부비동염 의 소견을 보이지 않는 환자 31 명을 대상으로 하였다. 평균 나 이는 33.4세(10 61)였고, 남자 22명, 여자 9명이었다.

만성 비부비동염 환자군은 비용종이 동반된 양측성 비부 비동염 환자 30 명을 대상으로 하였으며, 비내시경과 부비동 전산화단층촬영 $(\mathrm{CT})$ 으로 비부비동염을 진단하였으며, $\mathrm{MA}-$ $\mathrm{ST}$ 또는 알레르기 피부반응검사로 알레르기 비염은 제외하 였고, 폐기능 검사를 시행하여 천식을 제외하였다. 평균 나이 는 24.4세(14 54)였고, 남자 16명, 여자 14명이었다.

10 세 이하 소아, 폐기능 검사상 천식이 의심되는 환자, 이전 에 코수술을 받은 환자 그리고 최근 1 주 이내에 코와 관련 된 약을 투여한 경우는 제외하였다.

\section{방 법}

\section{$\mathrm{NO}$ 의 측정}

$\mathrm{NO}$ 의 농도는 화학 발광 분석기인 Sievers nitric oxide analyzer, NOA 280i(GE analytical instruments, boulder, CO, USA)를 이용하여 The American Thoracic So-
Fig. 1. Measuring of nasal nitric oxide (NO). NO concentration was measured using a chemiluminescence analyser. Nasal NO was analysed by aspiration at a sampling flow rate of $700 \mathrm{~mL} / \mathrm{min}$ with velum closure.

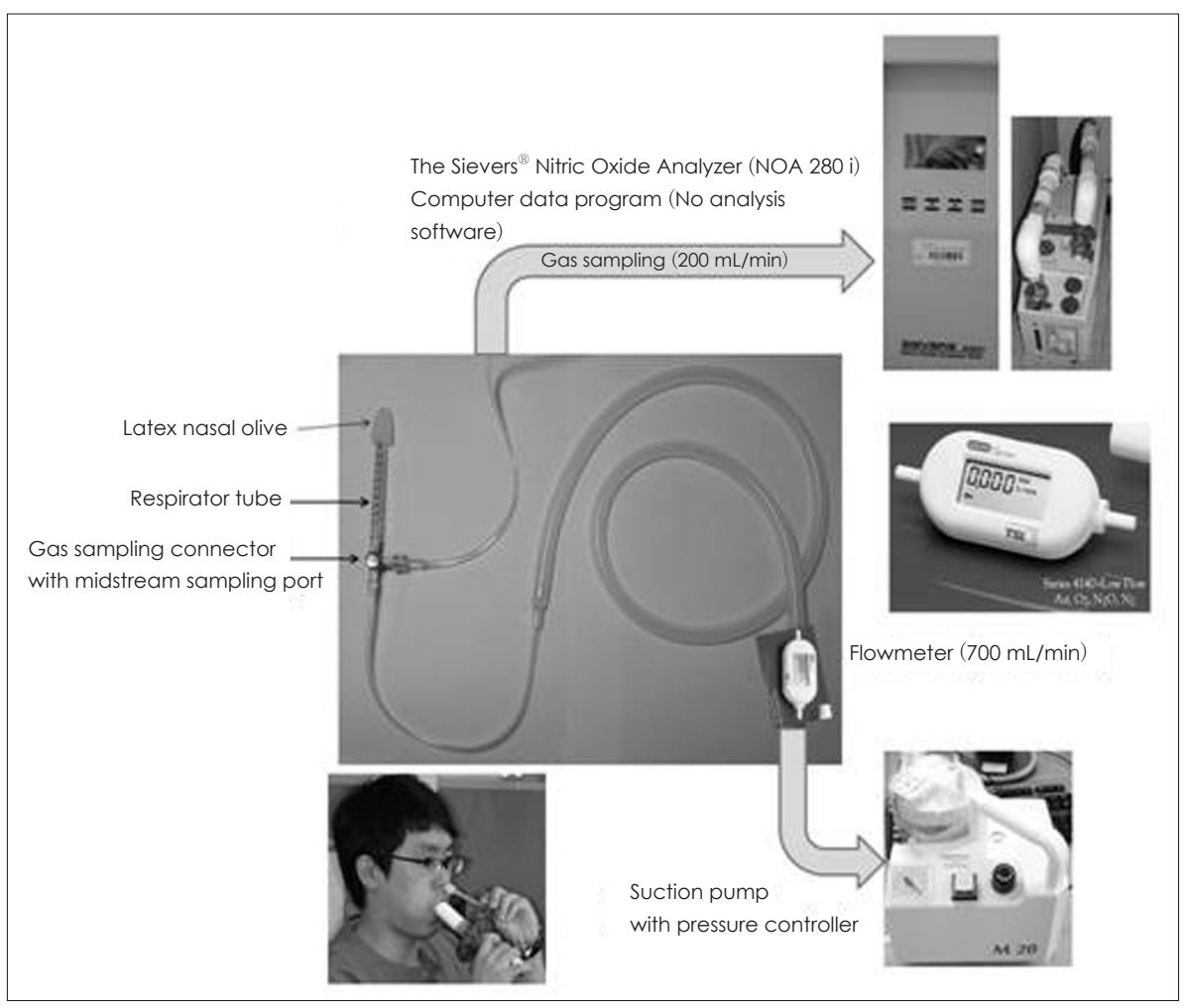


ciety and the European Respiratory Society(ATS/ERS) recommendations에 따라 측정하였다. ${ }^{2)}$

$\mathrm{nNO}$ 는 입천장 인두폐쇄를 시행하여 비강을 하부기도와 격리시킨 후, 분당 $700 \mathrm{~mL}$ 의 흡인 펌프를 통해 뽑아낸 기 류의 중간에서 분당 $200 \mathrm{~mL}$ 의 양으로 채취하여 컴퓨터로 분석하였다. Latex nasal olive를 이용하여 비공과 회로를 밀착시켰으며 반대측 비공은 열린 상태로 두었다. 약 $10 \mathrm{~cm}$ 의 respiration tube의 끝에 three way connector를 연결 하여 $200 \mathrm{~mL} / \mathrm{min}$ 로 $\mathrm{NO}$ 분석기로 이동할 기류를 채취하 였다(Fig. 1). 입천장 인두폐쇄는 총폐용량(total lung capacity)까지 숨을 들이 마신 후 호기압을 $10 \mathrm{~cm} \mathrm{H}_{2} \mathrm{O}$ 이상 으로 유지하면서 입으로 내쉬는 방법으로 시행되었고, main aspiration flow rate는 분당 $700 \mathrm{~mL}$ 로 하였다. 모든 측정 값은 매회 측정값이 $10 \%$ 이내의 차이를 보이는 2 회 측정치 의 평균값으로 하였으며, 컴퓨터를 이용하여 구한 plateau 를 측정값으로 정하였다.

하부 기도의 상태를 반영하는 $\mathrm{eNO}$ 는 $\mathrm{nNO}$ 측정처럼 10 $\mathrm{cm} \mathrm{H}_{2} \mathrm{O}$ 의 호기압으로 입천장 인두폐쇄를 시행하고, expiratory flow rate를 $50 \mathrm{~mL} / \mathrm{s}$ 로 plateau에 도달할 때의 농 도를 측정하였으며, 매회 측정값이 $10 \%$ 이내의 차이를 보이 는 2 회 측정치의 평균값으로 구하였다(Fig. 2).

$\mathrm{eNO}$ 는 측정된 평균값을 그대로 사용하였지만, $\mathrm{nNO}$ 는 대기의 $\mathrm{NO}$ 값의 영향을 많이 받아 측정된 $\mathrm{NO}$ 값에서 대기 중의 $\mathrm{NO}$ 값을 뺀 값을 보정하여 사용(purify $\mathrm{NO}, \mathrm{pNO}$ )하 였으며 본 연구의 $\mathrm{nNO}$ 값은 보정된 $\mathrm{NO}$ 값을 의미한다.

또한 대조군으로 사용한 비중격만곡증 환자의 경우 양측 의 차이가 날 수 있음을 고려하여 양측에서 각각 2 회 측정 하여 비교해 보았다.

모든 환자에게 설문지를 통하여 개인력과 알레르기 질환 의 병력 및 가족력(천식, 아토피, 알레르기 비염), 이비인후과

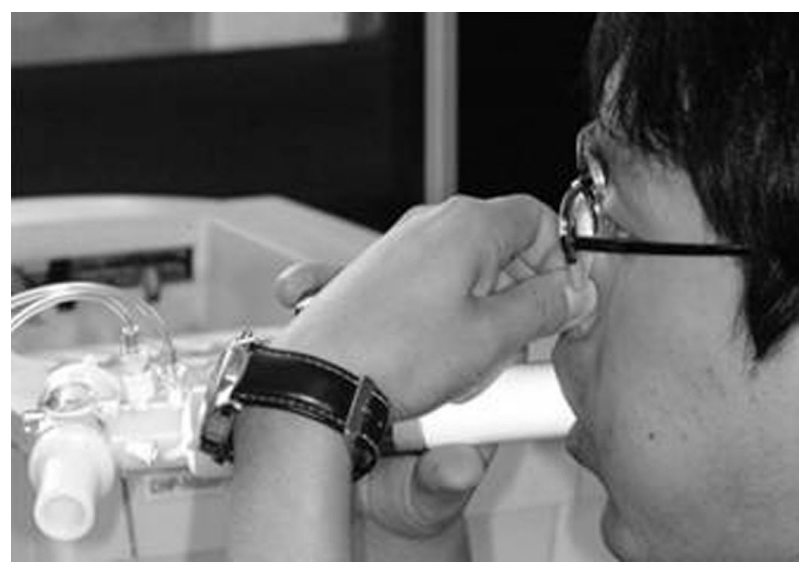

Fig. 2. Measuring of exhaled nitric oxide. Inhales to total lung capacity, and then orally exhales while maintaining a mouth pressure of $10 \mathrm{~cm} \mathrm{H}_{2} \mathrm{O}$.
수술력, 약물 복용력 및 알레르기 비염, 비부비동염, 천식의 증상을 체크하였다.

본 연구는 한양대학교 구리병원 기관생명윤리심의위원회 의 심사를 통과하였다.

\section{통계처리}

통계분석은 statistical package for social science(SPSS) soft ware(version 17.0 for windows)를 이용하였으 며, 평균비교는 Student's t-test를 사용하였고, 상관분석은 Pearson's correlation test를 사용하였다. 통계학적 유의 수준은 $95 \%$ 이상 $(p$-value $<0.05)$ 으로 하였다.

\section{결 과}

\section{정상 대조군에서의 $\mathrm{NO}$}

정상 대조군에서 $\mathrm{nNO}$ 의 평균 농도는 $241 \pm 89 \mathrm{ppb}$ 로 측 정되었고, $\mathrm{eNO}$ 는 $20.5 \pm 6.4 \mathrm{ppb}$ 로 측정되었다(Figs. 3 and 4). 양측 비강에서 측정한 값의 차이는 거의 없었다.

\section{알레르기 비염 군에서의 NO}

알레르기 비염군에서 $\mathrm{nNO}$ 는 평균 $332 \pm 125 \mathrm{ppb}$ 로 측정 되었으며, 정상 대조군과 비교하여 통계적으로 유의한 증가 를 보였다 $(p=0.002) . \mathrm{eNO}$ 는 $26.9 \pm 10.1 \mathrm{ppb}$ 로 측정되었고, 정상 대조군에 비해 통계적으로 유의한 증가를 보였다 $(p=$ 0.004)(Figs. 3 and 4).

\section{비용을 동반한 비부비동염 군에서의 NO}

비부비동염 군에서는 $\mathrm{nNO}$ 가 $89 \pm 55 \mathrm{ppb}$ 으로 측정되어

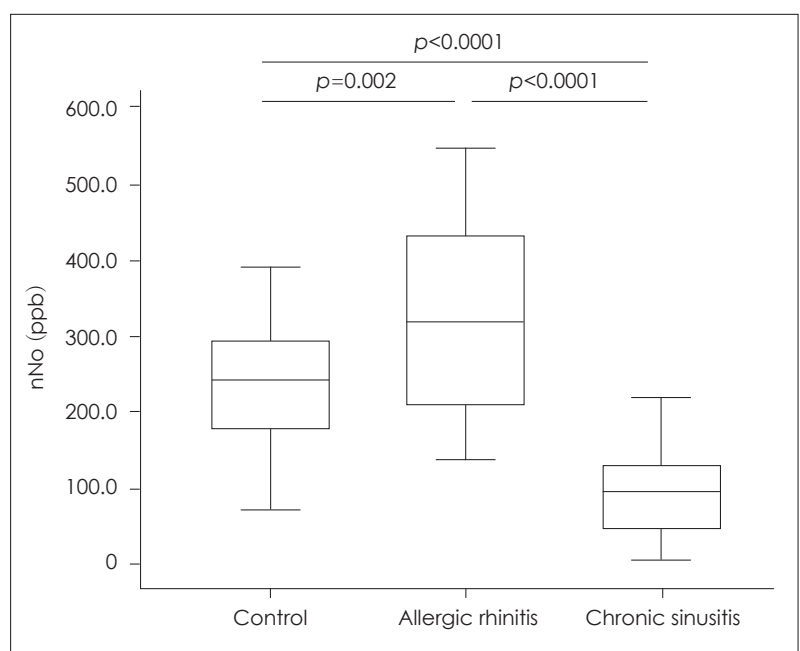

Fig. 3. Nasal NO (nNO) between groups. The mean nNO level was significantly increased in allergic rhinitis group and decreased in chronic rhinosinusitis group. 


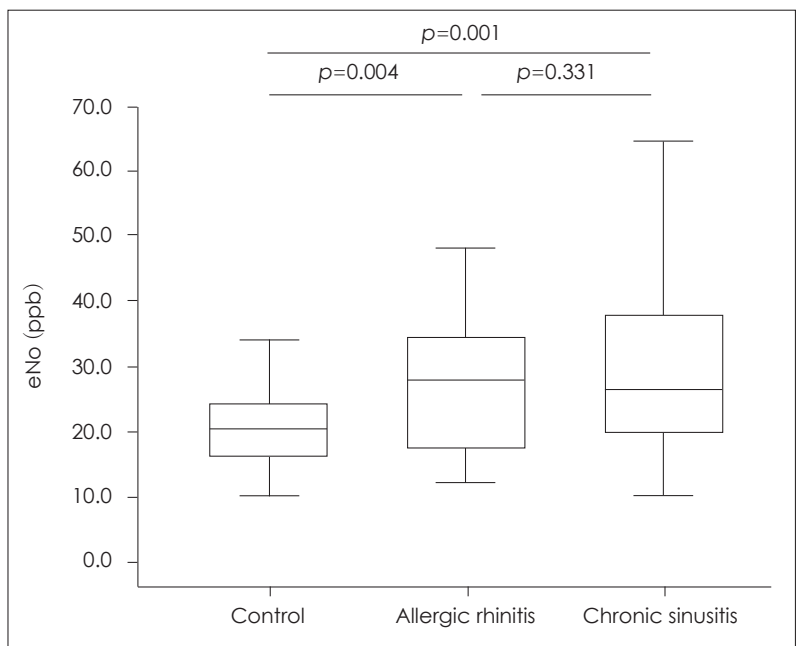

Fig. 4. Exhaled NO (eNO) between groups. The mean eNO level was significantly increased in allergic rhinitis group and chronic rhinosinusitis group both.

정상 대조군에 비해 통계적으로 유의하게 낮은 결과를 보였 다 $(p<0.0001)$. 그러나 $\mathrm{eNO}$ 는 비부비동염군에서 $29.8 \pm 12.8$ $\mathrm{ppb}$ 을 보여 정상 대조군에 비해 통계적으로 유의한 증가를 보였다( $p=0.001$ (Figs. 3 and 4).

\section{알레르기 비염 군과 비용을 동반한 비부비동염 군 사이의 차이}

$\mathrm{nNO}$ 는 $p<0.0001$ 로 두 군에서 유의한 차이가 보였으나 $\mathrm{eNO}$ 는 $p=0.331$ 로 두 군에서 유의한 차이를 보이지 않았다 (Figs. 3 and 4).

\section{고 찰}

산화질소(NO)는 인체 내 여러 세포에서 생성되는 높은 반 응성의 무기유리기로써 혈관의 긴장도 조절, 혈소판 기능 조 절, 신경 전달 및 비특이적 방어 작용에 관여하는 등 다양한 생물학적 기능을 하는 중요한 물질로 알려져 있다.") $\mathrm{NO}$ 는 $\mathrm{L}$-arginine을 기질로 산화질소 합성효소(NO synthase, $\mathrm{NOS}$ )로부터 생성된다. NOS는 세 가지 형태가 존재하는 것으 로 알려져 있는데, 혈관내피세포(eNOS)와 신경세포(nNOS) 에 항상 발현되어 있는 구성형(constitutive NOS, cNOS)과 염증에 의해 발현되는 유도형(inducible NOS, iNOS)이 있 다. 최근에는 eNOS, $\mathrm{nNOS}$ 에서도 유도형의 특성을 보이는 경우가 있으며, ${ }^{4)}$ 부비동 내에서 발현되는 iNOS도 구성형 의 특징을 보여 전통적인 NOS 분류법은 적절치 못한 것으 로 여겨지고 있다. ${ }^{5)}$

$\mathrm{NO}$ 의 분석은 화학 발광 분석기(chemiluminicence analyzer)를 이용하여 시행되는데, 산화질소와 오존 $\left(\mathrm{O}_{3}\right)$ 의 화
학 반응 시 발생하는 양전자 방출을 이용하여 산화질소의 농 도를 구하는 장치이다. 구강을 통해 측정하는 $\mathrm{eNO}$ 측정법 은 비교적 쉽고 간단하여 측정 방법의 차이가 별로 없고 표 준화되어 있으나, 비강을 통해 측정하는 $\mathrm{nNO}$ 의 측정법은 $\mathrm{eNO}$ 보다 복잡하고 연구자들마다 입천장 인두 폐쇄 방법이 다르며, main aspiration flow가 다르는 등 표준화된 방법 이 없었다. 이런 이유로 $\mathrm{eNO}$ 와 달리 $\mathrm{nNO}$ 는 정상치에 대한 표 준화된 데이터가 없었고, 임상에 이용되는 데 많은 어려움이 있었다. 국내에서는 고가의 기계장치의 문제와 이런 측정 방 법의 다양성의 이유로 연구가 되지 않았던 것으로 생각된다. 그러나 ATS/ERS에서 이전 연구방법을 종합하여 $\mathrm{nNO}$ 측정 법에 대한 권고안을 냄으로 어느 정도 측정방법의 지침은 마 련된 상태이며, 본 연구는 이의 지침대로 국내에서 처음 시 행한 직접 기체 상태의 $\mathrm{nNO}$ 연구로 의미가 있다고 하겠다.

$\mathrm{nNO}$ 측정 시 입천장 인두폐쇄를 시행하여 비강 및 부비동 을 하부기도부터 차단하여 하부기도의 NO 농도로부터 영향 을 받는 것을 막는 것이 중요하다. 반대로 $\mathrm{eNO}$ 를 측정할 때 도 비강 및 부비동의 $\mathrm{NO}$ 를 차단하는 방법으로 동일한 의 미가 있다. 입천장 인두폐쇄를 시행하는 방법은 이전 연구에 서 여러 가지가 소개되었는데, 최대흡기 후 숨을 참는 방법과 일정 압력으로 느린 호기를 시행하는 방법 두 가지가 가장 많 이 사용되며, 본 연구에서도 측정 기계에 호기 압력을 측정하 는 기능이 있어 후자를 이용하였다. 입천장 인두폐쇄가 적절 히 이루어지기 위해서는 최소한 $5 \mathrm{~cm} \mathrm{H}_{2} \mathrm{O}$ 의 압력으로 불어 야 하지만 $20 \mathrm{~cm} \mathrm{H}_{2} \mathrm{O}$ 를 넘게 되면 검사의 유지가 힘들기 때 문에 그 이하로 압력을 유지하여 plateau에 도달하는 농도 를 구해야 한다. ${ }^{2)}$ 본 연구에서는 호기 압력을 최소 $10 \mathrm{~cm}$ $\mathrm{H}_{2} \mathrm{O}$ 이상으로 유지하는 것을 감시하면서 입천장 인두폐쇄 가 되도록 하였다. ${ }^{6)}$

$\mathrm{NO}$ 의 농도의 결정에는 main aspiration flow rate가 가 장 중요한데, flow의 속도가 빠르다면 plateau의 NO값이 너무 낮게 측정되며, flow의 속도가 너무 느리다면 plateau 에 도달하는 시간이 오래 걸려 피검자 측면의 어려움이 있 고 상대적으로 높게 측정 된다. Struben 등ㄱㅇㅔ 의하면 느린 속도로 흡인 시 plateau에 달하는 시간이 오래 걸렸으며, 농 도는 높게 측정되었다고 하였으며, 일측 비공을 통해 흡인 하여 측정한 $\mathrm{NO}$ 농도에서 일중 변동 및 좌, 우측의 차이는 없었다고 하였으며, $700 \mathrm{~mL} / \mathrm{min}$ 의 속도로 흡인 시 가장 재 현성이 높고 좋은 결과를 얻었다고 하였다. 처음 해외 연구 자들이 처음 연구를 시작할 때는 흡인 속도를 $300 \mathrm{~mL} / \mathrm{min}$ 부터 $1,000 \mathrm{~mL} / \mathrm{min}$ 까지 다양하게 연구자들의 편의에 따라 시행하였지만, 최근 연구에서는 대부분 기류 속도를 700 $\mathrm{mL} / \mathrm{min}$ 로 하였을 때 가장 재현성이 높고 적절한 수치를 얻 
을 수 있다고 하여 이를 이용하고 있고 ATS/ERS 권고사항 에도 이를 적용하며 본 연구에서도 $700 \mathrm{~mL} / \mathrm{min}$ 를 사용하 였으며, 저자들도 검사자가 가장 편하게 받을 수 있고 재현 성이 높은 흡인 속도라고 생각한다. ${ }^{7}$

$\mathrm{eNO}$ 측정은 입천장 인두 폐쇄만 잘 된다면 호기만 적절 한 속도로 시행하면 문제없이 측정할 수 있으며 $\mathrm{nNO}$ 에 비 해 훨씬 간단하고 재현성이 높다. 최근에는 이런 간편성으로 인해 이동식 eNO 측정기인 Niox Mino ${ }^{\circledR}$ (Aerocrine, Sweden)가 개발되어 외래에서도 손쉽게 측정할 수 있게 많이 시 행되고 있으며, 국내에도 도입되어 임상적 연구가 이루어지 고 있다. 그러나 이런 이동식 $\mathrm{NO}$ 측정기로는 아직 더 복잡 한 장치와 방법이 필요한 $\mathrm{nNO}$ 를 측정할 수는 없다.

호기 내 산화질소는 대부분 상부기도에서 기원되며 주로 비 강과 부비동이 대부분을 차지한다. Ludberg 등은 기관 절 개술을 받은 환자의 $\mathrm{NO}$ 농도를 분석하여 기도에서 생성되 는 $\mathrm{NO}$ 의 대부분이 상부기도에서 생성되었다고 밝혔으며, 상악동 천자를 통해 부비동 내의 높은 $\mathrm{NO}$ 농도를 증명하였 다. ${ }^{9.10)}$ 즉, 부비동에서는 염증자극과 무관하게 지속적으로 $\mathrm{NO}$ 가 생성되며 그 농도는 20 25 ppm을 유지하고 있다. 비 강을 비롯한 상부기도에서 측정한 NO 농도는 400 900 ppb 이며, 하부기도에서는 $20 \mathrm{ppb}$ 이하의 농도로 측정된다고 보 고되고 있다. 측정방법의 다양성으로 $\mathrm{nNO}$ 는 그 정상 범위 가 비교적 넓으며, 본 연구에서는 정상 대조군에서는 $\mathrm{nNO}$ $241 \pm 89 \mathrm{ppb}, \mathrm{eNO}$ 는 $20.5 \pm 6.4 \mathrm{ppb}$ 로 측정되어, $\mathrm{eNO}$ 는 특별한 차이는 없지만 $\mathrm{nNO}$ 는 좀 낮게 측정되었다. 이는 $\mathrm{nNO}$ 가 대기의 $\mathrm{NO}$ 영향을 받는 것으로 분석되어 본 연구 에서는 측정된 $\mathrm{nNO}$ 에서 대기의 $\mathrm{NO}$ 를 뺀 값을 $\mathrm{pNO}$ 로 사 용하였기에 좀 낮게 측정된 것으로 생각된다. 또한 이는 인 종, 성별, 연령, 키 등의 다양한 개인적 성향에 따른 차이가 있다는 보고도 있어 이런 이유로 약간의 차이가 있을 수 있 다고 생각된다. 결론적으로 많은 연구에서 상기도에서는 대 부분의 산화질소가 부비동에서 생성되며, $\mathrm{nNO}$ 의 농도는 염 증자극 등이 변수가 되어 생성되는 산화질소의 양과 부비동 내 산화질소의 배출 정도와 관계된 부비동 자연공의 크기에 의해 결정된다고 주로 보고하고 있다. 하부기도에서는 정상 대조군에 비해 천식 환자에서 산화질소의 농도가 높은 것으 로 밝혀졌지만, 산화질소의 생성부위는 아직 불명확한 것으 로 되어 있다. ${ }^{11,12)}$

상부기도의 산화질소의 농도는 알레르기 비염 시 증가하며 비부비동염, 비용종성 질환에서 감소하며 섬모운동 장애를 보 이는 primary ciliary dyskinesia, cystic fibrosis 등의 질 환에서는 현저히 낮은 농도를 보이는 것으로 알려져 있으며 후자의 두 가지 질환에서는 $\mathrm{nNO}$ 가 진단적 가치가 있는 것
으로 알려져 있다. ${ }^{13)}$

많은 연구에서 알레르기 비염 환자에서 산화질소의 농도 의 증가가 확인되었다. Arnal 등ㄴ)은 알레르기 비염 환자를 증상 유무에 따라 두 개의 그룹으로 나누었고 두 그룹 모두에 서 $\mathrm{NO}$ 생성이 증가되어 있음을 보고하였다. 이는 알레르기 비염환자에서 증상 유무와 무관한 비점막의 지속적인 염증 반응에 의한 것으로 저자들은 설명하였다. Vass 등히은 천식 이 동반되지 않은 알레르기 비염 환자에서 정상 대조군과의 비교를 통해 eNO 및 adenosine의 증가를 보고하였으며, 이는 알레르기 비염 환자에서 상부 기도뿐 아니라 하부 기도 에도 염증을 가지고 있음을 의미한다. 본 연구에서도 알레 르기 비염 환자에서 $\mathrm{nNO}$ 와 $\mathrm{eNO}$ 모두 증가하는 것을 확인 하였다.

알레르기 비염과 같은 염증성 질환에서는 $\mathrm{NO}$ 의 생성이 증 가하지만 비용종이 동반된 비부비동염 환자에게서는 역설 적으로 $\mathrm{NO}$ 의 농도가 정상에 비해 낮게 측정된다. 이는 비부 비동염으로 인한 염증성 자극으로 인해 $\mathrm{NO}$ 의 생성은 증가 하지만 주 생성장소인 부비동의 입구가 용종으로 인해 막혀 있으므로 배출의 장애로 비강 내 $\mathrm{NO}$ 의 농도는 오히려 낮아 지는 것으로 생각된다. 비용종에 대한 약물치료, 수술적 치료 후 $\mathrm{nNO}$ 농도의 증가가 이를 뒷받침해 준다. ${ }^{16)}$ 본 연구에서 도 정상 대조군에 비해 비용종을 동반한 비부비동염 환자 에서 $\mathrm{nNO}$ 는 유의하게 현저하게 감소된 소견을 보였다.

만성 비부비동염에서는 비용종이 없어도 산화질소의 농도 가 낮게 측정된다고 보고되는데, 이는 비용종이 없더라도 비 부비동염에 의한 점막 비후로 인한 부비동공의 폐쇄로 인한 배출 감소와 오래된 만성 염증으로 인한 비부비동 상피의 손 상으로 인한 $\mathrm{NO}$ 의 생성의 저하가 원인으로 생각되며, Deja 등 근 상악동염 환자에서 상피 내 NOS의 발현이 감소되어 있 는 것을 밝혀 부비동염에서 $\mathrm{NO}$ 생성의 저하를 설명하였다.

비부비동염의 병리생태 원인으로 중요한 점액섬모운동과 $\mathrm{NO}$ 와도 밀접한 관계가 있는데 이는 일차성 섬모운동 이상증 (primary ciliary dyskinesia)에서 nNO의 농도는 현저히 감소하는 것으로 알 수 있으며, 이 질환의 선별 검사로 $\mathrm{nNO}$ 의 측정이 사용되기도 한다. 즉, 낮은 농도의 비내 산화질소 는 저하된 섬모운동과 관련이 있다고 할 수 있다. 섬모 운동 장애는 그 자체로도 비부비동염의 한 원인이 될 수도 있으 며, 항균작용을 하는 $\mathrm{NO}$ 의 낮은 농도는 또한 부비동내 침 입한 외부 미생물에 대한 방어력을 떨어뜨리는 원인이 될 수 있다. 반대로 비부비동염의 치료에서 $\mathrm{nNO}$ 를 이용하여 부비 동공의 개방 및 상피재생에 대한 monitoring으로 이용될 수 있을 것으로 생각되며, Degano 등은 부비동염의 약물 치료 후 nNO level의 증가를 보고하였다. ${ }^{18,19)}$ 
본 연구에서는 천식이 없는 만성 비부비동염 환자에서 $\mathrm{eNO}$ 의 증가가 관찰되었다. Guida 등 ${ }^{20}$ 의 보고에 의하면 만성 비부비동염 환자와 $\mathrm{eNO}$ 의 농도의 관계를 조사해 보았을 때 비용종의 유무, 천식의 동반이 $\mathrm{eNO}$ 의 증가와 관련이 있다 하 였다. 본 연구에서도 비강의 $\mathrm{nNO}$ 는 감소하였지만 $\mathrm{eNO}$ 는 증가하는 것으로 보아 천식 없이도 비용종의 경우 $\mathrm{eNO}$ 가 증가하는 것을 알 수 있었다.

본 연구는 국내에서 비강을 통해 가스형태의 $\mathrm{NO}$ 를 직접 측정하는 연구를 처음으로 실시했다는 데 의의가 있으며, 아 직 측정방법의 표준화에 대한 논란은 있으나 국외 보고와 유사한 결과를 보임으로서 국내에서도 연구해야 할 가치 있 고 의미 있는 연구로 생각되며, 좀 더 많은 수를 대상으로 더 다양한 임상양상과 비교 분석한다면 비강질환의 선별진단 및 추적관찰에 사용할 수 있을 것이고, 천식과의 비교 연구 를 통해 비질환의 병태생리의 연구에도 활용할 수 있을 것 으로 생각된다.

\section{REFERENCES}

1) Kim SH, Kim TH, Sohn JW, Yoon HJ, Shin DH, Park SS. Reference values and determinants of exhaled nitric oxide in healthy Korean adults. J Asthma 2010;47(5):563-7.

2) American Thoracic Society; European Respiratory Society. ATS/ ERS recommendations for standardized procedures for the online and offline measurement of exhaled lower respiratory nitric oxide and nasal nitric oxide, 2005. Am J Respir Crit Care Med 2005;171(8): 912-30.

3) Moncada S, Palmer RM, Higgs EA. Nitric oxide: physiology, pathophysiology, and pharmacology. Pharmacol Rev 1991;43(2):109-42.

4) Dawson TM, Snyder SH. Gases as biological messengers: nitric oxide and carbon monoxide in the brain. J Neurosci 1994;14(9):5147-59.

5) Lundberg JO, Weitzberg E, Rinder J, Rudehill A, Jansson O, Wiklund $\mathrm{NP}$, et al. Calcium-independent and steroid-resistant nitric oxide synthase activity in human paranasal sinus mucosa. Eur Respir J 1996; 9(7):1344-7.

6) Silkoff PE, McClean PA, Slutsky AS, Furlott HG, Hoffstein E, Wakita $\mathrm{S}$, et al. Marked flow-dependence of exhaled nitric oxide using a new technique to exclude nasal nitric oxide. Am J Respir Crit Care Med
1997;155(1):260-7.

7) Struben VM, Wieringa MH, Mantingh CJ, de Jongste JC, Feenstra L. Nasal NO measurement by direct sampling from the nose during breathhold: Aspiration flow, nasal resistance and reproducibility. Eur Arch Otorhinolaryngol 2006;263(8):723-8.

8) Lundberg JO, Weitzberg E, Nordvall SL, Kuylenstierna R, Lundberg JM, Alving K. Primarily nasal origin of exhaled nitric oxide and absence in Kartagener's syndrome. Eur Respir J 1994;7(8):1501-4.

9) Lundberg JO, Rinder J, Weitzberg E, Lundberg JM, Alving K. Nasally exhaled nitric oxide in humans originates mainly in the paranasal sinuses. Acta Physiol Scand 1994;152(4):431-2.

10) Lundberg JO, Farkas-Szallasi T, Weitzberg E, Rinder J, Lidholm J, Anggåard A, et al. High nitric oxide production in human paranasal sinuses. Nat Med 1995;1(4):370-3.

11) Kharitonov SA, Yates D, Robbins RA, Logan-Sinclair R, Shinebourne EA, Barnes PJ. Increased nitric oxide in exhaled air of asthmatic patients. Lancet 1994;343(8890):133-5.

12) Persson MG, Zetterström O, Agrenius V, Ihre E, Gustafsson LE. Single-breath nitric oxide measurements in asthmatic patients and smokers. Lancet 1994;343(8890):146-7.

13) Maniscalco M, Sofia M, Pelaia G. Nitric oxide in upper airways inflammatory diseases. Inflamm Res 2007;56(2):58-69.

14) Arnal JF, Didier A, Rami J, M'Rini C, Charlet JP, Serrano E, et al. Nasal nitric oxide is increased in allergic rhinitis. Clin Exp Allergy 1997; 27(4):358-62.

15) Vass G, Huszár E, Augusztinovicz M, Baktai G, Barát E, Herjavecz I, et al. The effect of allergic rhinitis on adenosine concentration in exhaled breath condensate. Clin Exp Allergy 2006;36(6):742-7.

16) Colantonio D, Brouillette L, Parikh A, Scadding GK. Paradoxical low nasal nitric oxide in nasal polyposis. Clin Exp Allergy 2002;32(5): 698-701.

17) Deja M, Busch T, Bachmann S, Riskowski K, Campean V, Wiedmann $\mathrm{B}$, et al. Reduced nitric oxide in sinus epithelium of patients with radiologic maxillary sinusitis and sepsis. Am J Respir Crit Care Med 2003;168(3):281-6.

18) Degano B, Génestal M, Serrano E, Rami J, Arnal JF. Effect of treatment on maxillary sinus and nasal nitric oxide concentrations in patients with nosocomial maxillary sinusitis. Chest 2005;128(3):1699705.

19) Ragab SM, Lund VJ, Saleh HA, Scadding G. Nasal nitric oxide in objective evaluation of chronic rhinosinusitis therapy. Allergy 2006;61(6): 717-24.

20) Guida G, Rolla G, Badiu I, Marsico P, Pizzimenti S, Bommarito L, et al. Determinants of exhaled nitric oxide in chronic rhinosinusitis. Chest 2010;137(3):658-64. 